This new analysis indicates that the beneficial effect of Cefaly for migraine prevention might be greater in patients with more frequent migraines, which is of interest for clinical practice.

(C) 2016 American Academy of Neurology
1. Schoenen J, Vandersmissen B, Jeangette S, et al. Migraine prevention with a supraorbital transcutaneous stimulator: a randomized controlled trial. Neurology 2013;80: 697-704.

2. Stokes ME, Davis CS, Koch GG. Categorical Data Using the SAS System, 2nd ed. Cary, NC: SAS Institute; 2000.

\title{
CORRECTION
}

Resting brain activity in disorders of consciousness: A systematic review and meta-analysis

In the article "Resting brain activity in disorders of consciousness: A systematic review and meta-analysis" by Y. Hannawi et al. (Neurology 2015;84:1272-1280), there is an error in a citation. In the sixth sentence under "Coordinate-based meta-analysis findings," reference 30 should replace reference 28. The corrected sentence should read: "Coordinate-based meta-analysis of patients with DOC who had anoxic brain injury ( 5 studies, 62 subjects, and 48 foci $)^{19,26,30,38,42}$ revealed significantly decreased activity in the precuneus, middle frontal gyrus, and bilateral medial dorsal nuclei of the thalamus." The authors regret the error. 


\title{
Neurology
}

\section{Resting brain activity in disorders of consciousness: A systematic review and meta-analysis \\ Neurology 2016;86;202 \\ DOI 10.1212/WNL.0000000000002301}

\section{This information is current as of January 11, 2016}

\author{
Updated Information \& \\ Services \\ including high resolution figures, can be found at: \\ http://n.neurology.org/content/86/2/202.full \\ Permissions \& Licensing \\ Information about reproducing this article in parts (figures,tables) or in \\ its entirety can be found online at: \\ http://www.neurology.org/about/about_the_journal\#permissions \\ Reprints \\ Information about ordering reprints can be found online: \\ http://n.neurology.org/subscribers/advertise
}

Neurology ${ }^{\circledR}$ is the official journal of the American Academy of Neurology. Published continuously since 1951, it is now a weekly with 48 issues per year. Copyright @ 2016 American Academy of Neurology. All rights reserved. Print ISSN: 0028-3878. Online ISSN: 1526-632X.

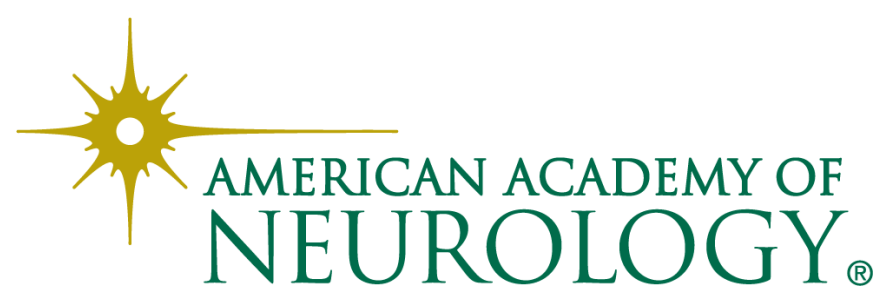

